\title{
Klumme: Vi tog fejl af Rusland
}

\section{Af Michael Ehrenreich}

Ruslands interventioner i Ukraine udgør en alvorlig fare for Europas sikkerhed og den globale orden. De seneste 25 års positive udvikling i forholdet mellem Øst og Vest ser desværre ud til at blive et midlertidigt fænomen.

Har de vestlige lande med USA og EU-kredsen i spidsen fejlvurderet Rusland? Spørgsmålet trænger sig mere og mere på, efterhånden som styret i Moskva fortsætter presset mod Ukraine samtidig med, at vi i vores del af verden gør klar til at markere $\mathrm{Mu}-$ rens fald for et kvart århundrede siden.

Dengang var der næsten ingen ende på glæden over, hvad der var sket. Og forventningerne til fremtiden var store. Fremover skulle vi, sagde man for 25 år siden, ikke alene leve i fred og sikkerhed. Det gamle Øst og Vest skulle også handle med hinanden og bindes sammen til fælles bedste.

Ikke mindst mange vestlige erhvervsledere havde et godt øje til perspektiverne. Sovjetunionen blev kort efter afløst af Rusland og en stribe randstater med næsten uendelige muligheder for udenlandske investeringer for dem, der turde og ville. Det gjorde ganske mange i de følgende år.

Derfor blev der i vestlige hovedstæder udfoldet store bestræbelser på at integrere specielt Rusland i den vestligt dominerede, internationale økonomi. Det blev et erklæret mål at lægge det enorme russiske landmassiv - der skreg på udvikling - åben for teknologi, know-how og forbrugsvarer.

Selv russernes traditionelle hadeobjekt nummer 1 - NATO - åbnede sine døre på klem. Russiske diplomater og officerer fik deres gang i den vestlige alliances hovedkvarter i Bruxelles i håb om, at sådanne tillidsskabende foranstaltninger, bakket op af formelle aftaler, ville begrave tidligere tiders fjendskab.

Undervejs udvidede NATO sin medlemskreds med en hel stribe øst-og centraleuropæiske lande samt flere tidligere sovjetrepublikker, og det udløste protester og vedvarende grynten fra Moskva. Men, sagde man til hinanden i NATO-kredsen, det var et spørgsmål om tid, før protesterne ville dø hen.

Michael Ehrenreich er direktør for Det Udenrigspolitiske Selskab. 
I de nye NATO-lande kløede man sig ganske vist lidt i skægget og advarede: vi kender Rusland sagde de, og ikke altid for det gode. Advarslerne gik på, om det virkelig kunne være rigtigt, at Rusland havde slået sig til tåls med sin skæbne, berøvet et imperium og den tilhørende stormagtsstatus. Men advarslerne blev fejet af bordet.

I dag ved vi, at advarslerne var rigtige. Det russiske overfald på Ukraine, med annekteringen af Krim-halvøen og aggressionerne mod det østlige Ukraine som de vigtigste elementer, har åbnet en hel verdens øjne for, at de seneste 25 års positive udvikling i forholdet mellem Øst og Vest desværre ser ud til at blive noget midlertidigt.

De russiske interventioner udgør en alvorlig fare for Europas sikkerhed og den globale orden. Det bærende princip om, at suveræne lande ikke bemægtiger sig dele af andre med magt, blev krænket helt åbenlyst af præsident Putin i marts måned med annekteringen af Krim.

Siden er den russiske fremfærd fortsat i forskellige udgaver og forklædninger i selve Ukraine ledsaget af en ildevarslende retorik med stærke revanchistiske toner om at korrigere historiske uretfærdigheder og genskabe Ruslands storhed, magt og indflydelse.

At NATO er blevet tvunget til at reagere, er helt åbenbart - og nødvendigt. Havde Alliancen ladet stå til, havde det formentlig blot skærpet den russiske appetit på at stramme kursen yderligere og fået sammenholdet mellem medlemslandene til at smuldre.

NATOs indre sammenhold og ydre afskrækkelse bygger på viljen til at imødegå eksterne trusler, også inden de for alvor materialiserer sig mod Alliancens geografiske territorium. Demonstreres denne vilje ikke offensivt, når udviklingen kræver det, vil Atlant-Pagten ikke være det papir værd, den er skrevet på.

Det netop overståede NATO-topmødes vigtigste formål var at gøre det klart for præsident Putin og den øvrige ledelse i Kreml, at går man videre og tager skridt til at destabilisere østlige medlemslande af Alliancen, som det sker i Ukraine, vil det udløse et robust svar fra NATO som helhed.

Målet blev søgt opnået med en lang række forskellige tiltag, hvoraf opstillingen af en militær reaktionsstyrke, der med kort varsel kan indsættes i de pågældende medlemslande, var det klart vigtigste. Styrken får bl.a. et bidrag fra Danmark.

Udviklingen siden marts rummer et stort paradoks. Præsident Putin har gennem de seneste år gjort det til et hovedmål at stække NATO, bl.a. ved at modarbejde Alliancens tilstedeværelse i det østlige Europa. Men han har opnået det modsatte.

Interventionerne i Ukraine har tydeliggjort for alle, hvorfor de senest ankomne lande i NATO-kredsen sætter så stor pris på politisk og militær beskyttelse. Udviklingen har tillige fået Europa og USA til igen at rykke tættere sammen efter en række år med megen kurren på tråden.

NATO har fået nyt liv. Netop som man var i gang med at drosle ned for engagementet i Afghanistan, og spørgsmålene om den vestlige alliances langsigtede berettigelse igen var begyndt at dukke op, er formålet med NATO blevet mere tydelig. Det blev synliggjort allerede i foråret, og det står endnu klarere her i efteråret 2014 